\title{
High serum iron and zinc decrease glutathione S-transferase among women with breast cancer
}

\author{
Nendyah Roestijawati*, Dwi Arini Ernawati*, and Diah Krisnansari*
}

ABSTRACT

\section{BACKGROUND}

Breast cancer in Indonesia ranks second as the most common cancer found in women after cervical cancer. Tumor cells express increased levels of antioxidant proteins to detoxify reactive oxygen species (ROS). Glutathione S-transferase (GST) is known to play a key role in the detoxification and reduction of ROS. Trace elements have nutritional benefits as essential cofactors for physiologic processes, but some can be toxic to humans. Accumulated evidence suggests that deficiency or excess of certain trace elements may be associated with risk of chronic diseases including cardiovascular diseases, diabetes and cancer. The aim of this research was to determine the correlation of the trace elements iron and zinc with the oxidative stress level of GST activity in women with breast cancer.

\section{METHODS}

An observational analytic study with cross sectional design was conducted involving 35 breast cancer women. Research subjects were women with breast cancer diagnosed by biopsy. Measurements of iron and zinc levels were performed using atomic absorption spectrometry, GST activity was measured using spectrophotometry. Data analysis was done with the Pearson correlation test.

\section{RESULTS}

The results showed that there was a significant relationship of serum iron with GST $(r=-0.487 ; p<0.05)$ and serum zinc with GST $(r=-0.409 ; p<0.01)$.

\section{CONCLUSION}

Our study demonstrated that the higher zinc and iron level, the lower GST level among breast cancer women. It is recommended to use zinc, iron and GST levels as biomarkers for breast cancer and its progression.

Keywords: Iron, zinc, glutathione S-transferase, breast cancer, women
*Department of Public Health and Community Medicine

Faculty of Medicine Jenderal Soedirman University Purwokerto

\section{Correspondence:}

Dr.dr.Nendyah Roestijawati, M.K.K Department of Public Health and Community

Medicine Faculty of Medicine

Jenderal Soedirman University

Purwokerto

J1. Dr. Gumbreg no. 1 Mersi

Purwokerto

Phone: +62281 622022

Fax. +62281624990

Email: nendyahr@yahoo.com

Date of first submission, November 6, 2017

Date of final revised submission,

February 21, 2018

Date of acceptance, February 22, 2018

This open access article is distributed under a Creative Commons AttributionNon Commercial-Share Alike 4.0 International License

Cite this article as: Roestijawati N, Ernawati DA, Krisnansari D. High serum iron and zinc decrease glutathione S-transferase among women with breast cancer. Univ Med 2018;37:25-30. doi: 10.18051/UnivMed.2018.v37.25-30 


\section{INTRODUCTION}

Breast cancer in Indonesia ranks second as the most common cancer found in women after cervical cancer. The number of cases of breast cancer has steadily increased, from 5,297 cases in $2004,7,850$ cases in $2005,8,238$ cases in 2006 , to 8,277 cases in 2007 . $^{(1)}$

Elevated rates of reactive oxygen species (ROS) have been detected in almost all cancers, where they promote many aspects of tumor development and progression. However, tumor cells also express increased levels of antioxidant proteins to detoxify ROS, suggesting that a delicate balance of intracellular ROS levels is required for cancer cell function. ${ }^{(2)}$

Glutathione S-transferase (GST) is known to play a key role in the detoxification and reduction of reactive oxygen species (ROS). According to research by Huang et al. (3) expression of GST-pi, a phase II detoxification enzyme, was up-regulated in breast cancers that exhibited higher oxidative stress and were associated with higher GST activity.

Trace elements have nutritional benefits as essential cofactors for physiologic processes, but some can be toxic to humans. Accumulated evidence suggests that deficiency or excess of certain trace elements may be associated with risk of chronic diseases including cardiovascular diseases, diabetes and cancer. ${ }^{(4)}$ Since the recognition of the possibility of the direct or indirect influence of trace elements in the development and prevention of malignant diseases, the contribution of the trace elements has been under scrutiny. ${ }^{(5)}$ Trace elements have been implicated in the pathogenesis of breast cancer. $^{(6)}$

According to Holanda et al. ${ }^{(7)}$ increases in zinc concentration in the cellular compartment and reduction of this trace element in the blood of patients with breast cancer appear to alter the activity of metalloproteinases 2 and 9 that contribute to the occurrence of malignancy. However, new studies that determine the effectiveness of these inhibitors in breast carcinoma are still needed.

Research by Jian et al. ${ }^{(8)}$ showed that mice fed an iron-deficient diet had significantly higher tumor volumes and lung metastasis compared to those fed normal iron diets. Iron deficiency mainly altered Notch but not TGF- $\beta$ and Wnt signaling in the primary tumor, leading to the activation of epithelial mesenchymal transition (EMT). This was revealed by increased expression of Snail and decreased expression of E-cadherin. Importantly, correcting iron deficiency by iron therapy reduced primary tumor volume, lung metastasis, and reversed EMT markers in mice. Furthermore, the research found that mild iron deficiency was significantly associated with lymph node invasion in young breast cancer patients.

On the other hand, research by Silva et al. ${ }^{(9)}$ showed that concentrations of trace elements are higher in neoplastic tissues (malignant and benign) when compared with normal tissues. Thus, there is still inconsistency of research results on the effect of trace element level on breast cancer.

The aim of this research was to determine the correlation of the trace elements iron and zinc with the oxidative stress level of GST activity in women with breast cancer.

\section{METHODS}

\section{Research design}

This study was an observational analytic study using cross- sectional design. The research was carried out within 6 months (July to December 2016) and was located at a hospital in Purwokerto, Banyumas District.

\section{Research subjects}

The subjects of the research were patients with breast cancer. Samples were selected by consecutive sampling in accordance with the inclusion criteria of breast cancer diagnosis based on biopsy, never received chemotherapy and 
willing to be a research subject. The sample size was 35 , based on a 0.05 significance level and power of $10 \%$, with a correlation coefficient of 0.5 .

\section{Laboratory analysis}

Blood samples were collected from the median cubital vein. Prior to blood sampling, subjects were asked to fast for 10 hours. Blood sampling was performed from 7:00 to 9:00 a.m. Approximately $10 \mathrm{~mL}$ of blood was drawn into small purple-top vacutainer tubes. Following clotting, the blood tube was centrifuged at 2500 $3000 \mathrm{~g}$ for $5 \mathrm{~min}$. The plasma supernatant was placed into a sterile acid-washed, metal ion-free microfuge tube, and stored frozen at " $20^{\circ} \mathrm{C}$ until required for the assay.(10)

Iron and zinc levels were determined using standard laboratory protocols. In brief, specimens were acid digested under high pressure in a microwave oven and then assayed for iron and zinc on a Perkin Elmer 3110 atomic absorption spectrometer (Waltham, MA, USA). We used calibration curves prepared from serially diluted iron and zinc standards (Merck, Germany). ${ }^{(10)}$

Measurement of GST activity was done by the method of Habig et al. ${ }^{(11)}$ In this method the GST activity is measured spectrophotometrically by following the yellow coloration as a result of 1-chloro-2,4-dinitrobenzene conjugation with GSH by GST. Laboratory analysis took place at the Research Laboratory, Faculty of Medicine, Jenderal Soedirman University, Purwokerto.

\section{Data analysis}

Data analysis was to determine whether there was a correlation using the Pearson correlation test. A $p$ value of $<0.05$ was considered significant.

\section{Ethical clearance}

This study was approved by the Commission on Health Research Ethics, Medical School, Jenderal Soedirman University (Unsoed) with Ref no: 152/KEPK/VII/2016.
Table 1.Distribution of subject characteristics

\begin{tabular}{lc}
\hline \multicolumn{1}{c}{ Characteristics } & Mean \pm SD \\
\hline Age $(\mathrm{yr})$ & $47.89 \pm 12.49$ \\
Serum iron $(\mu \mathrm{g} / \mathrm{dL})$ & $131.14 \pm 8.48$ \\
Serum zinc $(\mathrm{mg} / \mathrm{L})$ & $2.12 \pm 0.72$ \\
GST activity $(\mu \mathrm{mol} / \mathrm{dL})$ & $55.86 \pm 16.84$ \\
\hline
\end{tabular}

Table 2. Correlation of serum Iron and Zinc with GST activity $(\mathrm{n}=35)$

\begin{tabular}{lcc}
\hline Variables & $\begin{array}{c}\text { GST activity } \\
(\boldsymbol{\mu m o l} / \mathbf{d L})\end{array}$ & p value \\
\hline Serum iron $(\mu \mathrm{g} / \mathrm{dL})$ & $\mathrm{r}=-0.487$ & 0.003 \\
Serum zinc $(\mathrm{mg} / \mathrm{L})$ & $\mathrm{r}=-0.409$ & 0.015 \\
\hline
\end{tabular}

*Significant at 0.05 , tested by Pearson correlation test

\section{RESULTS}

The mean age of the subjects was $47.89 \pm$ 12.49 years, with the youngest subject being 25 years old and the oldest 76 years. Mean serum iron was $131.14 \mu \mathrm{g} / \mathrm{dL}$, mean serum zinc 2.12 $\mathrm{mg} / \mathrm{L}$ and mean GST content was $55.86 \mu \mathrm{mol} / \mathrm{L}$ as shown in Table 1.

The result of the correlation analysis of serum iron with GST showed a weak negative correlation $(p<0.05, r=-0.487)$, while the correlation of serum zinc with GST also showed a weak negative correlation $(\mathrm{p}<0.01, \mathrm{r}=-0.409)$ as shown in Table 2.

\section{DISCUSSION}

Mean serum zinc concentration in this study was $2.12 \mathrm{mg} / \mathrm{L}$, which was higher than the standard laboratory reference of $0.75-1.3 \mathrm{mg} /$ L). ${ }^{(12)}$ Zinc is required for both normal cell survival and for cell death via its role in apoptosis. Zinc may also regulate autophagy and other forms of survival due to its early sensitivity to cell stress. Thus, zinc could play a central role, regulating apoptosis and autophagy as well as immune cell function. Cancer cells are continuously stressed (genomic stress, endoplasmic-reticulum (ER) stress, nutrient stress, oxidant stress, etc) and selected for survival (likely by autophagy). Zinc has a spectrum of effects on cell death and 
survival, where zinc depletion induces cell death via apoptosis (or necrosis if apoptotic pathways are blocked) while sufficient zinc levels allow maintenance of cell survival pathways such as autophagy and regulation of reactive oxygen species. Cancer cells have up-regulated zinc importers, and most frequently have increased zinc levels, which allow them to survive. Based on these notions, means to locally regulate zinc levels to promote immune cell survival and tumor apoptosis are in order. ${ }^{(13,14)}$

The mean serum iron concentration in this study was $131.4 \mu \mathrm{g} / \mathrm{dL}$, which was at the high end of the standard laboratory reference range of $40-155 \mu \mathrm{g} / \mathrm{dL}$. ${ }^{(15)}$ According to the study by Wen et al. ${ }^{(16)}$ in Taiwan, elevated serum iron concentrations were associated with higher risks of cancer and cancer mortality. A Swedish cohort study by Gaur et al. ${ }^{(17)}$ found that increased serum iron concentrations were associated with slightly higher risks of postmenopausal breast cancer.

The mean GST activity in this study was $55.86 \mu \mathrm{mol} / \mathrm{dL}$. Glutathione-S-transferase (GST) is a cytoplasmic protein responsible for detoxification. The study by He et al. ${ }^{(18)}$ showed that cell proliferation and migration could be enhanced in greater concentrations of GST, where GST directly bound to the surface of the cancer cells. Glutathione-S-transferase activities were higher in the breast tumor than in the normal cytosolic fractions. ${ }^{(19)}$ Enginler et al. ${ }^{(20)}$ reported significantly higher GST enzyme in healthy tissues compared to tumor samples from the human mammary gland in a comparison of the malignant tumors and their healthy surrounding tissues.

Our study found negative correlations of serum iron and zinc with GST. According to Kasperczyk et al., ${ }^{(21)}$ in the group with high levels of calcium, magnesium, zinc, copper, iron, and selenium, the activity levels of glutathione peroxidase (GPx) and glutathione-S-transferase (GST) were lower than in the low level group. Higher levels of the examined metals are associated with elevated oxidative stress accompanied by decreased activities of some of the antioxidant enzymes.

Iron is a central element of the heme molecule, which is a critical part of hemoglobin and essential for oxygen transport. Heme is also a part of many essential enzymes such as catalase and the cytochrome series. ${ }^{(22)}$ However, when in abnormal expression, they seem to contribute to several pathological processes, including tumor growth, invasion and metastasis. Free iron is a pro-oxidant and can induce oxidative stress and DNA damage. The carcinogenicity of iron has been demonstrated in animal models, and epidemiologic studies have shown associations with several human cancers. However, a possible role of excess body iron stores or of elevated iron intake in breast carcinogenesis has received little attention epidemiologically. Over time a high intake of iron can lead to iron overload, which may disrupt iron homeostasis with a resulting increase in free iron, so contributing to the development of breast cancer.

Furthermore, body iron stores increase in women following menopause. Reactive oxygen species produced by normal aerobic cellular metabolism can lead to the release of free iron from ferritin. In the presence of superoxide radicals and hydrogen peroxide, stored ferric iron $\left(\mathrm{Fe}^{3+}\right)$ is reduced to ferrous iron $\left(\mathrm{Fe}^{2+}\right)$, which catalyzes the formation of the hydroxyl radical $\left({ }^{*} \mathrm{OH}\right)$. This in turn can promote lipid peroxidation, mutagenesis, DNA strand breaks, oncogene activation, and tumor suppressor inhibition, increasing the risk of breast cancer. In addition to its independent role as a prooxidant, high levels of free iron may potentiate the effects of estradiol, ethanol, and ionizing radiation - three established risk factors for breast cancer. ${ }^{(23)}$

Zinc occurs in all living cells as a constituent of metalloenzymes involved in major metabolic pathways. Zinc controls several enzymes of intermediary metabolism, DNA and RNA synthesis, gene expression, immunocompetence, and plays a significant role in homeostasis of hormones. ${ }^{(24)}$ High levels of $\mathrm{Zn}$ increased oxidative stress in breast cancer. The study by 
Seraj et al. ${ }^{(25)}$ showed that plasma zinc and malondialdehyde concentrations were significantly higher in patients as compared to the control group. It may also be suggested that increased oxidative stress in breast cancer patients may be attributed to the altered trace element level in such patients.

One limitation of this study was the absence of normal subjects (not having breast cancer) as controls. Thus there was no control data on the zinc, iron and GST concentrations for comparing with those of the study subjects and for demonstrating that the relationships between zinc, iron and GST occur only in women with breast cancer. Further studies need to be carried out using a controlled study design, e.g. a case control study design.

\section{CONCLUSIONS}

In the present study, we showed a negative correlation between serum iron and zinc with GST. This finding result support previous research that high accumulation of iron and zinc increased oxidative stress and decreased oxidant enzyme.

\section{CONFLICT OF INTEREST}

The authors declare to have no conflict of interest.

\section{ACKNOWLEDGEMENT}

Acknowledgements are due to Jenderal Soedirman University for funding and Faculty of Medicine for their cooperation and assistance.

\section{CONTRIBUTORS}

NR, DA, and DK contributed to drafting of the manuscript and acquisition of the data. DA and DK contributed to conception and design of the study. DA and DK contributed to revising the manuscript critically for important intellectual content. All authors read and approved the final manuscript.

\section{REFERENCES}

1. Departemen Kesehatan Republik Indonesia. Sistem kesehatan nasional. Jakarta: Departemen Kesehatan Republik Indonesia;2008.

2. Liou GY, Storz P. Reactive oxygen species in cancer. Free Radic Res 2010;44:479-96.

3. Huang J, Tan PH, Tan BK, et al. GST-pi expression correlates with oxidative stress and apoptosis in breast cancer. Oncol Rep 2004;12:921-5.

4. He K. Trace elements in nails as biomarkers in clinical research. Eur J Clin Invest 2011;41:98102. doi: 10.1111/j.1365-2362.2010.02373.x.

5. Adaramoye OA, Akinloye O, Olatunji IK. Trace elements and vitamin E status in Nigerian patients with prostate cancer. Afr Health Sci 2010;10:2-8.

6. Suzana S, Cham BG, Ahmad Rohi G, et al. Relationship between selenium and breast cancer: a case-control study in the Klang Valley. Singapore Med J 2009;50:265-9.

7. Holanda AON, de Oliveira ARS, Cruz KJC, et al. Zinc and metalloproteinases 2 and 9: what is their relation with breast cancer? Rev Assoc Med Bras 2017;63:78-84. doi: 10.1590/1806-9282.63.01.78.

8. Jian J, Yang Q, Shao Y, et al. A link between premenopausal iron deficiency and breast cancer malignancy. BMC Cancer 2013;13:307. https:// doi.org/10.1186/1471-2407-13-307.

9. Silva MP, Soave DF, Ribeiro-Silva A, et al. Trace elements as tumor biomarkers and prognostic factors in breast cancer: a study through energy dispersive $\mathrm{x}$-ray fluorescence. BMC Research Notes 2012;5:194. https://doi.org/10.1186/17560500-5-194.

10. Benoff S, Hauser R, Marmar JL, et al. Cadmium concentrations in blood and seminal plasma: correlations with sperm number and motility in three male populations (infertility patients, artificial insemination donors, and unselected volunteers). Mol Med 2009;15:248-62.

11. Habig WH, Pabst MJ, Jakoby WB. Glutathione S-transferases: the first enzymatic step in mercapturic acid formation. J Biol Chem 1974;249: 7130-9.

12. Szkup M, JurczakA, Brodowska A, et al. Analysis of relations between the level of $\mathrm{Mg}, \mathrm{Zn}, \mathrm{Ca}, \mathrm{Cu}$, and $\mathrm{Fe}$ and depressiveness in postmenopausal women. Biol Trace Elem Res 2017;176:56-63.

13. John E, Laskow TC, Buchser WJ, et al. Zinc in innate and adaptive tumor immunity. J Transl Med 2010;8:118. doi: 10.1186/1479-5876-8-118.

14. Maret W. Molecular aspects of human cellular zinc homeostasis: redox control of zinc potentials and zinc signals. Biometals 2009;22:149-57.

15. Gomella LG, Haist HS, editors. Laboratory 
diagnosis: chemistry, immunology, serology. In: Clinician's pocket reference: the Scut monkey. $11^{\text {th }}$ ed. New York: McGraw-Hill;2007.p.53-94.

16. Wen CP, Lee JH, Tai YP, et al. High serum iron is associated with increased cancer risk. Cancer Res 2014;74:6589-97.

17. Gaur A, Collins H, Wulaningsih W, et al. Iron metabolism and risk of cancer in the Swedish AMORIS study. Cancer Causes Control 2013;24: 1393-402.

18. He S, Liao TT, Chen YT, et al. Glutathione-Stransferase enhances proliferation-migration and protects against shikonin-induced cell death in breast cancer cells. Kaohsiung J Med Sci 2011;27: 477-84.

19. Oguztuzun S, Abu-Hijleh A, Coban T, et al. GST isoenzymes in matched normal and neoplastic breast tissue. Neoplasma 2011;58:304-10.

20. Enginler SO, Toydemir TSF, Ates A, et al. Examination of oxidative/antioxidative status and trace element level in dogs with mammary tumors. Bulg J Agric Sci 2015;21:1086-91.
21. Kasperczyk A, Dobrakowski M, Horak S, et al The influence of macro and trace elements on sperm quality. J Trace Elem Med Biol 2015;30:1539. doi: 10.1016/j.jtemb.2014.12.007.

22. Brewer JG. Iron and copper toxicity in diseases of ageing, particularly atherosclerosis and Alzheimer's disease. Exp Biol Med 2007;232:323 35 .

23. Kabat GC, Rohan TE. Does excess iron play a role in breast carcinogenesis? an unresolved hypothesis. Cancer Causes Control 2007;18:104753.

24. Jamakala O, Rani UA. Amelioration effect of zinc and iron supplementation on selected oxidative stress enzymes in liver and kidney of cadmiumtreated male Albino rat. Toxicol Int 2015;22:1-9. doi: 10.4103/0971-6580.172289.

25. Seraj AK, Shankhar M, Raju KD, et al. Antioxidants and lipid peroxidation status in women with breast cancer. Int Med J Malaysia 2015;14:71-5. 